\title{
A Conceptual Model for School-Based Management Operation and Quality Assurance in Nigerian Secondary Schools
}

\author{
Adeolu Joshua Ayeni ${ }^{1}$ \& Williams Olusola Ibukun ${ }^{2}$ \\ ${ }^{1}$ Deputy Director of Education, Ondo State Quality Education Assurance Agency, Akure, Nigeria \\ ${ }^{2}$ Department of Educational Management, Adekunle Ajasin University, Akungba-Akoko, Nigeria \\ Correspondence: Adeolu Joshua Ayeni. Deputy Director of Education, Ondo State Quality Education Assurance \\ Agency, P.O. Box 2347, Akure, Nigeria. Tel: 234-813-965-4848. E-mail: ayeniadeolu@yahoo.com
}

Received: November 5, 2012

doi:10.5539/jel.v2n2p36

\author{
Accepted: January 11, 2013 \\ Online Published: April 2, 2013 \\ URL: http://dx.doi.org/10.5539/jel.v2n2p36
}

\begin{abstract}
This paper examined the School-Based Management Committee's (SBMC) involvement and effectiveness in school governance, curriculum implementation and students' learning outcomes in Nigerian secondary schools; the major challenges facing effective operation of SBMCs were identified as low capacity of key members of the SBMCs; poor attendance of members at meetings due to lack of incentives and financial support from the government; lack of cooperation from the schools; and PTA's resistance to the SBMC initiatives; these resulted in ineffective school management and low level of students' academic achievement. It was concluded that a conceptual model of inter-relatedness be adopted to strengthen the operational capacity of SBMCs for efficient service delivery and quality learning outcomes in secondary schools.
\end{abstract}

Keywords: school-based management committee, transformational process, teacher's instructional task, principal's leadership task, student learning outcome, conceptual model, quality assurance

\section{Introduction}

School-Based Management is the process of devolution of power and authority to significant stakeholders to perform statutory responsibilities in the administration, monitoring, evaluation and review of education policy issues for sustainable goal-oriented governance and effective teaching and learning activities to achieve set standards and quality learning outcomes in schools. The decentralization of decision-making process in educational policy issues entrenches democratic principles, community participation, equity, as well as integration of diverse local interests and needs in school management.

Quality assurance-oriented school-based management is a pro-active intervention management strategy for improving the quality of institutional governance, resource inputs, curriculum implementation, and students' academic achievement in schools. The societal quest for quality education delivery and product value (output) underscores the relevance of quality assurance-oriented school-based management in the school system.

The decentralization policy on school management is premised on the fact that local communities are closer to the schools and understand their problems and needs better and therefore are more effective in decision-making on education policy issues in schools. School-based management committees are prominent and strategic in coping with the task of improving the quality of educational practices in such countries as Indonesia, Hong Kong, Thailand, Australia, Belgium, Denmark, Finland, France, Netherlands, England and Wales, New Zealand, and the USA.

\section{Global Perspective on School-Based Management for Quality Assurance in Education}

Quality assurance in education is the efficient management, monitoring, supervision, assessment and reviews of the resource inputs and curriculum implementation process to produce quality learning outcomes (product value) that meet set standards and expectations of the society. Robinson (1994) views quality assurance as the programme of activities that are performed by an organization for the purpose of making the quality of its product or service meets the prescribed standards. The desired quality is achieved by anticipation and avoidance of faults or mistakes which enables the top management in the organization to be focused in work scheduling, itemizing the procedures, monitoring and evaluating the process, documenting and reviewing the operational strategies, and communicating decisions to all concerned for the attainment of set goals. 
Venkaiah (1995) sees quality assurance as a management principle that ensures equitable treatment in the planning, controlling and implementation of all the functions and activities of an organization for the purpose of achieving the goals set. Harvey (1999) defines quality assurance as the process of providing the required resource inputs, ensuring effective control and improving the process for the purpose of raising the quality of output to meet the prescribed standards and fulfill public accountability. This thought underscores the issue of raising the "product value" and learners' potentials development through effective transformational process (teaching and learning), and effective supervision and management in the school system.

Raouf (2008) opines that quality assurance in education is the continual improvement in the methods of implementing the various aspects of educational programs and activities in an institution of learning to meet the desires of the stakeholders in education. This perspective is premised on the principle of Deming's cycle of continuous improvement, which is fundamentally based upon Plan, Do, Check and Act cycle (PDCA). This process enables the school-based management committee to strategically articulate educational programs; systematically monitor the implementation process; and critically assess and evaluate the quality of resource inputs, teaching-learning process and students' learning outcomes in line with the set standards. Interventions are provided by identifying the key issues that need to be reviewed and improved upon in the course of implementing the plan so as to ensure that significant agreement exists between the original goals and what is actually achieved, and acting on the plan full scale in a systematic process to facilitate feedback and reviews with those concerned (Deming, 1986; Stahl, 1998; Temponi, 2005).

The practice of School-Based Management (SBM) dates back to 1909 in the United States of America and regarded as the Teacher Council Movement (TCM), which featured teacher-dominated councils that made policy recommendations for the administration of individual schools. By 1930 the school councils were restructured to become the Democratic Administration Movement (DAM) which represents a range of perspectives and interests (teachers, students, parents and communities) in democratic governance of the schools. In the mid-1960s SBM became the Community Control Movement (CCM) which allowed a wide range of constituents, including leaders of community groups and minority parents in school policy decisions.

The SBM policy became a more popular education reform initiative in 1980s. In the United States, A Nation at Risk during which American children seriously lag behind international students of equal age and grade in academics (Gardner, 1983) led to the adoption of SBM as part of the intervention strategies to improve the quality of education in many schools and states, most especially in Illinois. In 1988, the School Reform Act instituted school councils as mandatory throughout the United States, which involves the decentralization of power and authority to schools by the State legislature for self-management in the basic areas of decision-making, budgeting, resource utilization, teaching and learning activities, and personnel matters in order to meet the yearnings and aspirations of the citizenry for improvement in the quality of education management system and learning outcomes. By the middle of the 1990s the SBM concept became increasingly important and expanded massively with the momentum of revolution and assumed different forms in different countries (Boonmee, 2002; Eurydice, 2007; Murphy and Beck, 1995).

Similarly, in Great Britain, the 1988 Education Reform Act under the Thatcher government devolved power and authority to school communities to constitute management boards as mandatory corporate bodies consisting of the head teacher and governors elected by the parents, teachers, and representatives of the local authority. Under the Act, public secondary schools became autonomous and grant-maintained (GM) schools, owned and managed solely by each school's governing board, composed of 10-to-15-member entity, including the head teacher and parents' representatives; devoid of local education authority control. The study on this approach revealed that student achievement improved by 0.25 of a standard deviation in pass rates on standardized examinations (Clark, 2009).

In Belgium, Denmark, Finland, and Netherlands, the Central Governments enacted appropriate legislation to decentralize power and authority with full autonomy to schools to establish and operate managing bodies in partnership with the Local stakeholders to manage, regulate and take decisions on education policy matters; curriculum and teaching methods; learners' evaluation; personnel selection, dismissal and discipline; infrastructure; and other learning resources to guarantee the best use of public funds; and the raising and judicious use of private funds for the overall well-being of the citizenry and production of quality outputs from the educational institutions (Eurydice, 2007).

Research on School-Based Management in Indonesia indicated that there is a dramatic improvement in students' achievement due to the effective operation of government's policy guidelines to establish mandatory corporate school governing councils in accordance with Education Act 20/2003 on National Education System which 
allows maximum involvement of local communities in the management of the school to achieve better quality education. Article 56 of the Act provides that the communities members are required to participate actively in the quality improvement of educational services, which include: strategic planning, curriculum implementation, and monitoring and evaluation of educational programmes through the educational council and school council, while the Government through the Ministry of National Education regulates the power and authority vested in the school councils, as well as the operational procedures/characteristics and formation of membership and structure of a school council (Agustinus, 2008).

The Indonesian Education Act 20/2003 describes a school council as an independent body established to provide technical advice, directions and support for personnel, facilities and equipment, and monitoring of a school (Article 56). The power and authority of a school council relates to its four major roles, which are: 1) to be an advisory agency in determining and/or approving educational policies at the school level; 2) serving as supporting agency in the school both in financial and non-financial matters; 3) functioning as controlling agency both for the purpose of transparency and accountability at school level; and 4) to be a mediator between school, government, and community on educational matters (Agustinus, 2008).

In Nigeria, the National Policy on Education, Section 12 (104b) (Federal Republic of Nigeria, 2004) allows close participation and involvement of the communities, at the local level, in the administration and management of their schools. Since the community has legitimate mandate in education, it behoves on the traditional institutions to mobilise and coordinate their subjects to integrate their skills and wealth of experience into the school programme in order to maximize their contributions in their expertise and best practice through periodic monitoring, reviewing, evaluating and given constructive advice on key functions in curriculum delivery, critical infrastructure, capacity building, instructional materials/equipment, staff and students welfare, management and support mechanisms, and school-community relationship. This is another dimension of transparency, accountability and commitment that will ensure quality service delivery and attainment of the overall goal of education in schools. The relationship between the school and the community is indeed a symbiotic one, since the function of one complements the other.

The school thrives on effective interrelationships within it and with its relevant publics. The school requires a lot of human, materials, physical facilities and financial resources for building the capacity of the education system to be able to deliver high quality and relevant curriculum to learners of all ages. Consequently, the School-Based Management Committee (SBMC) is recognized as a viable tool for promoting effective community participation, commitment, transparency, accountability, supportive services and best practices in school planning, management, monitoring and evaluation of performance of school administrators, teachers and learners to ensure quality service delivery and learning outcomes.

In a bid to ensure effective participation of local communities in the management of affairs of schools, the National Council on Education (NCE) in 2006 approved the establishment of SBMCs in all primary and secondary schools in Nigeria, as part of government strategy to re-structure the school administrative process and ensure inclusive participation of stakeholders in the school management at the community level. The SBMC is made up of 12 to 19 people in each school. This is expected to be achieved through the involvement of meaningful, close, strong and goal-oriented partnership between the school authority and other relevant stakeholders (Parent-Teachers Association (PTA), Old Students Association, Communities, Traditional Institution, Civil Society Organizations, Faith-Based Organizations, Ministries, and other professional and social institutions). This synergy is necessary because a virile and responsive school-community relationship is a building block for a sustainable quality education (Ayeni, 2010; Aggarwal, 1981; Balogun et al, 1981; Universal Basic Education Commission, 2011).

\section{Result}

\subsection{Challenges Facing the Operation of School-Based Management Committee}

The operation of the SBMC is faced with a number of problems, some of which have been identified by Pushpanadham (2000) in a study conducted on Indian schools as follows:

Many of the SBMC members have limited knowledge of school budget, physical plant, personnel policy issues, conflict resolution and other statutory matters in which they are expected to offer professional and technical inputs in decision making and performance evaluation for sustainable improvement in the school system. These noticeable gaps in administrative capacity of SBMC are major challenges to school effectiveness. 
$>$ Politicization of school policy issues such as selection of textbooks and disciplinary problems often caused by little knowledge and inadequate experience of some SBMC members constitute encumbrance to school administration.

It is worthy to mention that SBMCs have been established in many secondary schools in Nigeria in line with the directive of the National Council on Education but only few of them are operating effectively. The findings by the Federal Ministry of Education (2011) revealed that a significant proportion of $60 \%$ of schools are without functional SBMCs. This situation has been attributed to problems such as inadequate sensitization and advocacy for the communities to understand the enormous benefits to be derived from their genuine participation in school governance, particularly in raising teaching and learning standards, and quality of outputs in schools.

The operation of the SBMC is also faced with the challenges of low administrative capacity of key members of the SBMCs; poor attendance of members at meetings due to lack of incentives and financial support from the government; lack of cooperation from the school managers; teachers' misconception of the role of the SBMC as an interference on their profession; PTA's role conflict and resistance to the SBMC initiatives, due to misconception of the SBMCs functions which is believed to be mere duplication of the PTA's roles; politicization of the selection of school uniform and release of school facilities for usage by members of the community. Consequently, many of the problems inhibiting effective teaching and learning from achieving the desired outcomes have not been adequately addressed.

\subsection{Impact of School-Based Management on Students'Academic Performance}

Students' academic performance hinges on effective operation of the school management. The identified challenges in the SBMCs operations made their members to be deficient in the performance of their tasks and have been partly responsible for ineffective school management, while the students' academic achievement is still below 40\% in Nigerian secondary schools. The Federal Ministry of Education (2006) reported that students' academic performance in the Senior Secondary School Certificate Examination (SSCE) conducted between 2000 and 2006 was below fifty percent. Bello-Osagie \& Olugbamila (2009) also reported that in the 2009 November/December Senior Secondary School Certificate Examination conducted by the National Examination Council (NECO-SSCE), out of the total number of 234,682 Nigerian candidates who sat for the examination, only 4,223 obtained credit level passes and above in five subjects including English and Mathematics, which is a 98.2\% failure rate. Owadiae (2010) reported that in 2009 May/June Senior Secondary Certificate Examination conducted by the West African Examinations Council, only 25.99 percent of the candidates obtained credit passes and above in five subjects including English Language and Mathematics, while in the 2010 May/June WASSCE, out of the $1,135,557$ candidates that sat for the examination, only $337,071(24.94 \%)$ candidates obtained five credit level passes and above in subjects including English Language and Mathematics.

Furthermore, in Nigeria, the 2011 May/June Senior Secondary Certificate Examination conducted by West African Examinations Council shows that only 30.99\% of the 1,540,250 candidates obtained credit level passes and above in five subjects including English Language and Mathematics, while in 2012 May/June WASSCE, $649,156(38.81 \%)$ of the $1,672,224$ candidates that sat for the examination obtained five credit level passes and above in subjects including English Language and Mathematics .in the 36 states of the Federation and the Federal Capital Territory (Owadiae, 2011; Owadiae, 2012).

In the same vein, the percentage of students who obtained credit level passes in five subjects and above including English Language and Mathematics in public secondary schools among the States in South-west, Nigeria in the 2010 Senior School Certificate Examination conducted by the West African Examinations Council (WASSCE), reflect the following percentage scores: Ekiti State (21.25\%), Lagos State (9.11\%), Ogun State (10.55\%), Ondo State (30.17\%), Osun State (5.05\%), and 5.94\% in Oyo State (Federal Ministry of Education, 2011).

The performance under review depicts low academic achievement of students in Nigeria. The abysmal performance of students could be a reflection of gap in resource inputs, quality of curriculum management and poor academic standard of students, which has perhaps been attributed to the gap in the input-process-output system, and the systemic mal-functioning in the school management procedures being practiced in secondary schools, which often leads to steady decline in students' academic performance and depicts non realization of quality assurance in education system. It is therefore necessary to develop a conceptual model to address the imbalances and strengthen the SBMCs to ensure effective governance and teaching-learning process to achieve better outputs in secondary schools.

\subsection{School-Based Management Model of Quality Assurance}

The task of providing quality education for the citizenry is highly demanding and requires a robust capacity of 
the school management to organize the human and material resources to meet the various needs and challenges facing school administration in curriculum implementation, so that the education aims and objectives can be achieved. This situation calls for an improvement in the school management system approach in practice; an attempt has therefore been made to build conceptual model for the inter-relatedness of key variables in school-based management for quality assurance in resource inputs, teachers' instructional task performance, principals' supervisory roles, and students' academic performance. The operational structure and components of the school-based management model is explained diagrammatically below:

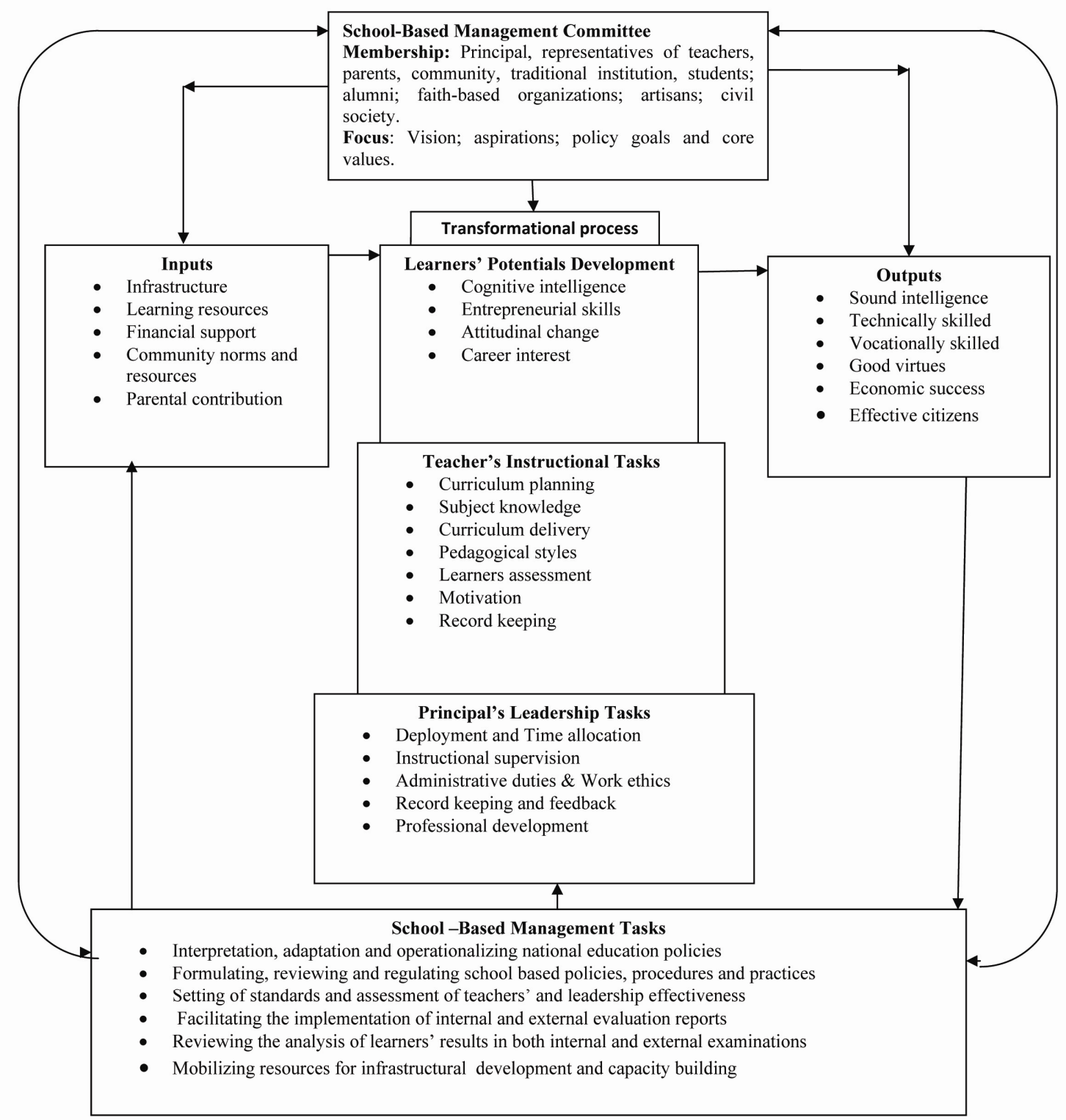

Figure 1. School-based management model (SBM-Model)

The learners' training and potential development is the central focus in the transformation process. This is ensured through goal-oriented activities, effective and efficient operations of the key transformational agents (teachers and principal). The role of the teacher is pivotal to the intellectual, skill and character development of the learners. The teacher is responsible for curriculum planning and delivery, learners' assessment, record keeping, and motivation of learners for active participation in learning activities while the principal ensures effective organization, utilization, supervision and management of curricula and co-curricular activities, and public accountability in the use of resources geared towards quality development of the learners' potentials that 
occupy the centre stage of the educational system.

The teaching-learning process is supervised and enhanced by the principal through instructional modeling, mentoring, monitoring and evaluation, record keeping and feedback. The supervisory process enables the principal to gather necessary information on teachers' cognate knowledge, teaching styles, appropriateness of the instructional materials, and learners' skills and participation. These provide the bases for determining the level of progress being made in the implementation of the curriculum and the challenges that need to be addressed in teachers' capacity for effective transformational process to achieve the educational policy goals.

In pursuit of quality assurance in the transformational process within the school system, Ayeni (2010) views the school as an open system that operates a network of inter-relationships among individuals and activities within it, and with the external environment, particularly the stakeholders who formulate the National Policy on Education that stipulates the objectives and operational procedure for the school administration and curriculum implementation. In a bid to translate the educational objectives into reality, the principal gives accurate feedback on school activities to the school-based management committee and seeks for inputs in form of expert opinion, and other relevant support in human resource, finance, facilities and materials to bridge the identified gaps in teaching and learning processes, and promote public accountability in the use of resources that are provided for quality development of the learners' potentials.

The school-based management committee members meet periodically to deliberate on the success recorded on school programs and activities, and challenges. The quality of the transformational process and outputs from the school is further enhanced by the school-based management committee through a comprehensive analytical review of the school academic activities and programmes according to the educational policy goals and procedures. The purpose is to determine the institutional strengths and weaknesses in curriculum planning and delivery, teachers' quality and quantity, resource utilization, learners' participation and level of instructional supervision by the top management in the school.

The involvement of the school-based management committee in the school governance ensures sustainable inter-dependent relationship between the school and the community, by promoting good value system and recognizing the cooperation, participation and support of significant and relevant stakeholders in the setting of standards and ensuring quality in the management of school resources. This dynamic process of relationship strengthens the community intervention and mandate in education and instills sense of collective ownership, responsibility and commitment to the progress of the school's programs, activities, development of physical structures, learning facilities and improvement in learning outcome. This is a pro-active means of achieving the desired goals in community inputs, instructional process and outputs that guarantee quality human capital development in knowledge, technical and vocational skills, and character for sustainable self-reliance of the individuals and the overall development of the nation for mutual benefit of the citizenry.

\subsection{Benefits of Quality Assurance-Oriented School-Based Management Committee}

The opportunities that are inherent in quality assurance-oriented school and community partnership, which are relevant for school-based management are highlighted by Ayeni (2012) as follows:

$>$ A quality assurance-oriented school-based management committee will facilitate greater synergy among stakeholders in education and contribute to the growing body of knowledge on institutional management and quality of teaching. The emphasis placed on teachers' pedagogic practices and students' learning processes will enable members of the community, teachers and students to have clear information about learning outcomes and develop strong commitment to the achievement of educational goals.

$>$ Effective school-based management committee is a building block for school and community partnership in school governance. This process will enable the key stakeholders in education to receive firsthand information on the quality and quantity of resource inputs; strengths and weaknesses inherent in teachers' instructional task performance and the leadership behavior of principals; staff and students welfare; and stimulate government and other stakeholders to see the need for adequate provision of learning facilities and capacity building of principals and teachers in order to improve institutional management and curriculum delivery for better learning outcomes in secondary schools.

$>$ It is envisaged that the emphasis being placed on quality assurance-oriented school-based management committee will encourage school principals and members of the community to pay special attention to resource inputs, efficient and transparent use of resources, increased participation of stakeholders in decision making process for better institutional management and improved outcomes for the learners (sound knowledge, skills, attitude, values and effective citizens). 
> A strong SBMC will enable stakeholders to evaluate their school programs and to-establish result-oriented procedures that would help those teachers and students that do not perform well to achieve optimum productivity and quality learning outcome. This will provide principals, teachers and members of the community with relevant information on the effects and efficacy of teaching and learning activities on students' performance and stimulate them to find realistic solutions to problems of quality in secondary education; so that academic norms are not undermined at the expense of social norms, but both would complement each other.

\section{Conclusion}

The paper concluded that effective school-based management committee is the engine room for school and community partnership and vital for school effectiveness and students' success, while the challenges that teachers and principals faced in the tasks of instructional performance and supervision require strong political will to stimulate desired commitment and goal-oriented partnership between the school and other stakeholders for optimal resource inputs, organization, utilization and management of learning facilities to maximize the quality of teaching and improve the standard of students' learning outcome in Nigerian secondary schools.

\section{Recommendations}

The following recommendations are made in order to overcome the challenges militating against effective operation of quality assurance-oriented school-based management committees in Nigerian secondary schools.

$>\quad$ The Government at both the Federal and State levels should formulate operational policy guidelines and enact appropriate laws to give legal backing and create enabling environment for effective operation of the SBMCs. This will no doubt ensure sustainable improvement in the quality of management and outputs of the Nigerian secondary education system.

$>\quad$ The Government should reward outstanding SBMCs members by commendation and publicly recognize their services to foster psychological interest, active participation and full commitment to the tasks of school governance, monitoring and evaluation of teaching and learning activities, resource mobilization, maintenance of infrastructure and supervision of school projects, and advocacy and sensitization of community members for maximum contribution and support services for school administration and curriculum delivery to achieve sustainable quality education and students' learning outcomes in Nigerian secondary schools.

$>\quad$ The Ministry of Education should organize cluster-type training workshops and seminars on quality assurance-oriented school based management to build the capacity of members of SBMCs on their roles, responsibilities, operational policy guidelines, procedures, and practices of SBMC-Model. This is necessary to make the SBMCs members to be efficient and effective in the performance of their tasks to achieve the set educational goals and standards in Nigerian secondary schools.

$>$ Government and local SBMCs should collaborate to organize public enlightenment campaign to sensitize the entire stakeholders on the values and roles of SBMC for better understanding of their responsibilities, particularly school leadership, resource management and performance evaluation in order to reduce conflicts to the barest minimum among members concerning the roles set.

\section{References}

Aggawral, J. F. (1981). Theory and practice of education: Philosophical and sociological bases of education (p. 104). New Delhi: Vikas Publishing House, PVT, Ltd.

Agustinus, B. (2008). The implementation of school-based management in Indonesia: Creating conflicts in regional levels. Journal of NTT Studies, 1(1), 16-27.

Ayeni, A. J. (2012). Improving school and community partnership for sustainable quality assurance in secondary schools in Nigeria. International Journal of Research Studies in Education, 1(2), 95-102. http://dx.doi.org/10.5861/ijrse.2012.v1i2.49

Ayeni. A. J. (2010). Teachers' instructional task performance and principals' supervisory roles as correlates of quality assurance in secondary schools in Ondo State. Doctoral dissertation, Obafemi Awolowo University, Ile-Ife, Nigeria.

Balogun, D. A., Okon, S. E., Musaazi, J. C. S., \& Thakur, A. S. (1981). Principles and Practice of Education. Lagos: Macmillan Nigeria Ltd.

Bello-Osagie, K., \& Olugbamila, A. (2009, December 31). Events that shape education. The Nation, B2.

Boonmee, N. (2002). Executive summary of report on national pilot study: Learning reform schools for developing quality of learners. Thailand: Office of the National Education Commission (ONEC). 
Clark, D. (2009). The performance and competitive effects of school autonomy. Journal of Political Economy, 117(4), 745-783. http://dx.doi.org/10.1086/605604

Deming, W. E. (1986). Out of the crisis. Cambridge: Cambridge University Press.

Eurydice European Unit. (2007). School autonomy in Europe: Policies and measures. Brussels: Eurydice Information Network on Education.

Federal Ministry of Education. (2011). The state of education in Nigeria: beyond access. Abuja: Federal Inspectorate Services.

Federal Ministry of Education. (2011). Statistics of Education in Nigeria: 2006-2010. Abuja: Statistics and NEMIS Branch, Federal Ministry of Education.

Federal Ministry of Education. (2006). Operation reach all secondary schools inspection exercise. Abuja: Federal Ministry of Education Publication.

Federal Republic of Nigeria. (2004). National Policy on Education. Lagos: NERDC Press.

Gardner, D. P. (1983). A Nation at Risk: The Implicative for Educational Reform - Report to the U.S. Department of Education, National Commission on Excellence in Education. Washington, DC.

Harvey, L. (1999). An assessment of past and current approaches to quality in higher education. Austrialian Journal of Education, 43(3).

Murphy, J., \& Beck, L. (1995). School-based Management as School Reform: Taking Stock, Thousand Oaks. California: Corwin Press.

Owadiae, I. (2012, August 11). West African Senior School Certificate Examination results. The Punch, 8.

Owadiae, I. (2011, August 11). West African Senior School Certificate Examination results. The Nation, 4.

Owadiae, I. (2010, August 31). West African Senior School Certificate Examination results. The Punch, 39.

Pushpanadham. K. (2000). A study on the decentralized management of district primary education programme. Ph.D. Unpublished Thesis, Maharaja Sayajirao University, Baroda, India.

Raouf, A. (2008). Continuous improvement of higher education quality. Retrieved from http://www.aacsb.edu/accreditation/default.asp

Robinson, B. (1994). Ensuring quality in the planning and development of distance learning courses. Paper presented at the $20^{\text {th }}$ Anniversary International Conference on Distance Learning, Columbia (September 20-22, 1994).

Stahl, T. (1998). Self assessment: A road to quality assurance for continuing training. Vocational training. European Journal (pp.33-45). Retrieved from http://www.abet.org/the basics.shtml

Temponi, C. (2005). Continuous improvement framework: Implications for academia. Quality assurance in education, 13, 17-36. http://dx.doi.org/10.1108/09684880510578632

Universal Basic Education Commission. (2011). Revised national guidelines for the development of school-based management committees in Nigeria. Abuja: Social Mobilization Department, Universal Basic Education Commission with the support of esspin/UKaid.

Venkaiah, V. (1995). Quality assurance in student support services. In M. S. Rao, G. Srinivasacharyulu, \& J. Mohanraj (Eds), Quality assurance in distance education (pp. 151-159). India: D.K. Fine Art Press Limited. 